\title{
In response to the article titled Thoughts on the Ethics of Gestational Surrogacy: Perspectives from Religions, Western Liberalism, and Comparisons with Adoption Issue Date: January 2020
}

\author{
Salma Shabaik ${ }^{1}$ (D) Anita Nelson ${ }^{1}$ \\ Received: 5 May 2020 / Accepted: 10 May 2020 / Published online: 25 May 2020
}

(C) Springer Science+Business Media, LLC, part of Springer Nature 2020

We read with interest the article by Dr. Raywat Deonandan on the religious perspectives of gestational surrogacy. The article states that in Islam, the "definition of a firstborn son is particularly important, as he will carry the family name and its honor into the future." The article then states that an embryo created years in advance of a younger sibling being born naturally begs the question of who the firstborn son is.

Islamic texts have not differed between children based on their birth order and does not give preference to a firstborn son over any other child. This construct is cultural, predates Islam, and has no basis in the religion. We think this distinction is important to clarify to reduce misconceptions about Islam and Muslims.

We agree that Sunni Muslim jurists have generally ruled that gestational surrogacy is prohibited under Islamic law, although this prohibition remains highly debated among Sunni Muslim scholars. The most commonly cited reason by
Sunni jurists for this prohibition is the struggle in determining who the legal parent of the child is, the main concern being that this struggle could result in strife between the parties involved, thereby destabilizing that family unit [1].

We wish to thank Dr. Deonandan for his contribution to this important field and his article in shedding light on the nuances of this ethical discussion.

\section{Reference}

1. Padela AI, Klima K, Duivenbode R. Producing parenthood: Islamic bioethical perspectives \& normative implications. The New Bioethics. 2020;26(1):17-37. https://doi.org/10.1080/20502877. 2020.1729575 .

Publisher's note Springer Nature remains neutral with regard to jurisdictional claims in published maps and institutional affiliations.
Salma Shabaik

Sacramento, CA, USA 